\author{
Contato \\ UNICAMP \\ Instituto de Filosofia e Ciências Humanas \\ R. Cora Coralina, 100 \\ 13083-896 - Campinas - São Paulo - Brasil \\ alexandra.tedesco@gmail.com
}

\section{ENTRE FRANÇA E}

ALEMANHA: OS ESTILOS DE VIDA DA ELITE LETRADA DE BUENOS AIRES NA PRIMEIRA METADE DO SÉCULO XX

\section{- Alexandra Dias Ferraz Tedesco"*}

Universidade Estadual de Campinas

Campinas - São Paulo - Brasil

\title{
Resumo
}

Este artigo se propõe a explorar a dinâmica do universo cultural da Argentina na primeira metade do século XX a partir da observação da circulação de distintas atitudes intelectuais. Isso significa analisar, em paralelo às disputas teóricas entre positivistas e espiritualistas e suas reverberações institucionais, os estilos de vida que informavam as discordâncias teóricas. Parto da emergência de um grupo de intelectuais nacionalistas argentinos que ganha espaço a partir da radicalização do discurso crítico dos anos 1920, no intuito de analisar a decadência da referência francesa - grande orientadora das expectativas da elite letrada argentina da virada do século - e a ascensão de referências alemãs e espanholas que viabilizavam não apenas a divulgação de ideias novas, como também, de um novo

\section{Palavras-chave}

"sentido do jogo" para os intelectuais argentinos.

História argentina-históriaintelectual-intelectuais-história daselites-Alemanha.

* Todas as obras e todos os documentos utilizados na pesquisa e na elaboração do artigo são citados nas notas e na bibliografia. Todos os autores participaram de todas as fases do artigo. Uma versão aproximada do texto foi disponibilizada pelo Repositório de Teses da UNICAMP, 2018.

** Doutora em História pela Universidade Estadual de Campinas (Unicamp, 2018), foi professora substituta do Departamento de História da Universidade Federal do Triângulo Mineiro (UFTM), IELACHS, Uberaba-MG, Brasil, de abril a outubro de 2019. 


\begin{abstract}
This article proposes to explore the dynamics of the cultural universe of Argentina in the first half of the $20^{\text {th }}$ century observing the circulation of different intellectual attitudes. This means analyzing, in parallel to the theoretical disputes between positivists and spiritualists and their institutional reverberations, the lifestyles that informed the theoretical disagreements. I begin with the emergence of a specific group of Argentine nationalist intellectuals that gains space through the radicalization of the critical discourse in the 1920s, in order to analyze the decline of the French reference - a great guide to the expectations of the Argentine literate elite at the turn of the century - and the emergence of German and Spanish references that enabled not only the dissemination of new ideas but also a new "sense of the game" for Argentine intellectuals.
\end{abstract}

\title{
Keywords
}

Argentine history - intellectual history - intellectuals - history of elites - Germany. 
Beatriz Sarlo, em Modernidade Periférica, se vale de Raymond Williams para qualificar certa atitude diante do moderno enquanto manifestação de uma estrutura de sentimento específica. ${ }^{1}$ Em seus termos

O tema da idade de ouro é a configuração que emerge das incertezas causadas pelo novo: ele restaura no plano do simbólico uma ordem que é considerada mais justa, embora nunca tenha existido objetivamente, ou seja, é mais uma resposta à mudança do que uma lembrança do passado. É por isso que a idade de ouro não é uma reconstrução realista ou histórica, mas uma diretriz que, no passado, é basicamente acrônica e atópica: de alguma forma uma utopia em que tecidos misturam desejos, projetos e, sem dúvida, também memórias coletivas. (SARLO, 2010, p. 32).

Entre idealizações do passado, disputas por identidade e reorganização dos espaços intelectuais, a Argentina das primeiras décadas do século XX oferece uma vasta gama de possibilidades para a circulação do discurso crítico, tal como o entende Koselleck (1999). Descrevendo uma dessas vias, a saber, a ascensão de um setor nacionalista nas letras argentinas, em fins da década de 1920, Sarlo pontua que, em oposição às vanguardas do mesmo período, "este programa tem como condição básica uma leitura da história, caracterizada primeiro por um esquema heroico (a patriada) e em seguida por uma construção de romance, que implica a possibilidade de mudança e redenção sobre a base de um pronunciado monocausalismo" (SARLO, 2010, p. 212). ${ }^{2}$ Diferentemente, portanto, da geração modernista protagonizada pelo cosmopolitismo de Borges, para quem o passado era um mosaico de memórias familiares, se sobressaem figuras como as de Leopoldo Lugones, Alfredo Palacios e Scalabrini Ortiz, para os quais a crise dos anos 1930 tem, sobretudo, dimensões morais. ${ }^{3}$ As visões do centenário e suas dimensões projetivas,

\footnotetext{
1 Este artigo é parte de minha tese de doutorado, defendida no departamento de História da Unicamp, intitulada A Argentina na periferia do tempo, sob orientação da profa. Dra. Silvana Barbosa Rubino, a quem agradeço neste momento de divulgação do trabalho.

2 "este programa tiene como condición básica una lectura de la história, caracterizada primero por un esquema heroico (la patriada) y luego por una construcción de romance, que implica la posibildad de cambio y redención, sobre la base de un pronunciado monocausalismo" (2010, p. 212).

3 É importante lembrar que, nas antípodas de Sur, permanecem os escritores dedicados a temas sociais, no geral provenientes de Boedo e agrupados em torno da revista Claridad. A impressão é que a literatura de esquerda é muito mais pulverizada em revistas como Brújula, de Rodolgo Puiggrós e Víctor Luis Molinari (1930-1931), como Castelnuevo na Nervio, anarquista, a partir de 1931, como Raul Gonzáles Tuñon na Contra em março e agosto de 1933, como a Columna, de 1937 a 1942, e como Héctor P. Agosti de 1946 a 1947 na marxista Tiempo e Expresión. Para análise mais detalhada das tensões entre o grupo da Florida e Boedo, é possível consultar Altamirano e Sarlo (1997) e Silva (2005).
} 
que prefiguravam uma Argentina repleta de futuro, nos anos 1930 já não inspiravam mais confiança. Era preciso, na leitura de Funes (2006), demonstrar a existência ontológica da nação que se pretendia restaurar.

Em vista da ascensão de um setor específico de intelectuais nacionalistas argentinos que ganha espaço a partir da radicalização do discurso crítico dos anos 1920, proponho neste artigo compreender essa dinâmica intelectual a partir de um rastreio dos estilos de vida intelectuais que emergiram naquele contexto. Nesse sentido, o objetivo é bastante pontual: capturar a decadência da referência francesa - grande orientadora das expectativas da elite letrada argentina da virada do século, notadamente aquela de atitude positivista - e a ascensão de referências alemãs e espanholas que traziam em seu bojo não apenas uma nova concepção sobre o entendimento da crise mas, também, uma nova categorização da figura do intelectual, um novo "sentido do jogo". Schorske (1981), introduzindo suas meditações sobre Viena, propõe que o historiador se atente ao entrecruzamento de duas dimensões: diacronicamente, que os textos sejam analisados a partir dos textos que lhes informaram e, sincronicamente, que sejam postos em diálogo com outras manifestações coetâneas. Essa é a inspiração que orienta a composição desta reflexão sobre as primeiras décadas do século XX argentino: em paralelo às disputas teóricas entre positivistas e espiritualistas (observação sincrônica) e às suas reverberações institucionais, esse ponto da análise circunscreve as querelas teóricas aos estilos de vida que as informavam (perspectiva diacrônica). Observar esses entrecruzamentos é assumir, para todos os efeitos, que a história de uma narrativa é também a história do escamoteamento de outras.

\section{A busca por identidade nos dois lados do Reno}

Não poucas narrativas sobre a América Latina - desde aquelas de cunho ensaístico até as robustas formulações acadêmicas como as da Teoria da Dependência - se debruçaram sobre as tensões que envolveram a formação de sua identidade, as querelas acerca do "centro" do ponto de vista da periferia e as reivindicações de "continuidade patrimonial" com a Europa. Perguntas como "quem somos?" ou "por que não somos diferentes?" compuseram o imaginário latino-americano ao longo dos últimos duzentos anos. No caso argentino, notadamente, a referência francesa foi uma das chaves mestras para a superação da herança colonial espanhola que a geração de 1880 julgava perniciosa para seus projetos modernizadores. Advogar a continuidade patrimonial europeia a partir da aproximação com os modos de vida e as instituições francesas se converteu em uma das consignas centrais da moder- 
nidade argentina, e convivia com desenvoltura com a literatura de tom xenófobo ${ }^{4}$ que procurava relegar às periferias simbólicas a herança espanhola.

A França, Meridiano de Greenwich literário (CASANOVA, 2002a), funcionava como cânone central da intelectualidade portenha do começo do século, tanto pela proeminência que desempenhava no cenário europeu quanto pela possibilidade que oferecia às elites letradas argentinas de avalizar, através de um sólido comércio de prestígio, suas próprias práticas e temas, afinal, também no universo intelectual "é preciso ser antigo para ter alguma chance de ser moderno ou de decretar a modernidade" (CASANOVA, 2002a, p. 118). O apego da classe letrada argentina à simbologia da belle époque francesa é bastante conhecido. Desde os salões literários da geração de 1837, passando pelo sucesso das filosofias positivistas na virada do século, até a arquitetura portenha, são diversos os níveis através dos quais se pode observar essa circulação; na síntese de Braun, o século XIX é permeado por essa tendência: "havia interesse no progresso, mas também em mostrar que pertencia ao mundo privilegiado do além mar. Um certo espírito exibicionista se revelou a partir dos anos cinquenta" (BRAUN; CACCIATORE, 1996, p. 34, tradução nossa). ${ }^{5}$ A Buenos Aires que se moderniza na virada do século chegou a ser considerada, como é sabido, a Paris americana, a ponto de Clemenceau tenha podido afirmar, quando em visita, que Buenos Aires era mesmo uma grande cidade europeia. Protagonistas dessa mimese, as famílias mais abastadas e tradicionais, com grandes volumes de capital cultural, se empenharam em atualizar os círculos letrados de Buenos Aires nesse repertório.

O imaginário francês atuava, para além de instância consagradora, como fornecedor de um modelo de conduta letrada (SVAMPA, 1994). Conforme salienta Ringer, se na Alemanha o intelectual esteve "totalmente excluído do mundo aristocrático das pequenas cortes alemãs" (RINGER, 1992, p. 22, tradução nossa) ${ }^{6}$ na França ele é o próprio homme civilisé. Do mesmo modo, em oposição à ideia da Bildung alemã enquanto característica que adere ao indivíduo a partir do autocultivo, o homem civilizado francês tem a erudição como um bem que se adquire e se utiliza, ponto de partida de perten-

\footnotetext{
${ }^{4}$ Dentre os autores dessa literatura xenófoba pode-se destacar Miguel Cané, José Antonio Wilde, Lucio Lopes e Martín Garcia Merou. Ver Vásquez-Rial (1996).

5 "Habia en ello interés en el progresso, pero también en mostrar que se pertenecía al privilegiado mundo de alén mares. Um cierto espíritu exhibicionista se mostro desde la década del cincuenta" (BRAUN; CACCIATORE, 1996, p. 34).

6 "totally excluded from the aristocratic world of the small german courts" (RINGER, 1992, p. 22).
} 
cimentos sociais e comunitários. Essa distinção importa na medida em que era esse modelo de "homem civilizado", polido e cortês, e não outro tipo de atitude intelectual, que funcionava como mecanismo distintivo das tradicionais elites argentinas vinculadas à renda pecuária: em oposição às grandes massas de imigrantes, mas também à burguesia que lentamente enriquecia, a referência aos modos franceses não se restringia, assim, a uma questão de etiqueta. Nos termos de Rolland (2004), a França funciona, no fim do XIX latino-americano, como paradigma, e a adoção dos modelos franceses esteve ligada à defesa de uma ideia muito particular de república

dessa forma, a referência à França, país cuja presença econômica é secundária no continente, é fundamental, porque ela é cultural antes de ser política, universalista mas longínqua e, por isso, pouco ameaçadora, e porque o militantismo da terceira república francesa fornece modelos que são julgados como sendo parcialmente transportáveis pelas elites latino-americanas. (ROLLAND, 2004, p. 247)

A partir da circulação de nomes de proa do campo letrado argentino, expressa em meditações de viagem, crônicas periodísticas e, eventualmente, em preferências abertamente reivindicadas - como no caso de Delfina Bunge, alfabetizada em francês que, conta-se, teria confessado pensar nesse idioma e em seguida traduzir mentalmente para o espanhol - se conformará esse vigoroso espaço cultural nas primeiras décadas do século XX argentino informado pela referência francesa. Na leitura de Rapoport e Seoane, nesse sentido, entre 1890 e 1914

o hedonismo em geral das classes altas européias, a permissividade de suas conexões sociais, que iam desde a participação nas festas rufianescas do maquereaux até o consumo de drogas, junto com o refinamento artístico e cultural da capital francesa, atraíram a visita ou o estadia de restacueros e outros personagens portenhos em busca de adquirir uma pátina de distinção e superioridade. (RAPOPORT; SEOANE, 2007, p. 377, tradução nossa) ${ }^{7}$

As famílias ricas e tradicionais de Buenos Aires, como os Alvear, os Anchorena e os Ocampo, protagonizam um trânsito que permanecerá vigoroso até avançadas décadas do século XX. Conforme a clássica crônica de David

\footnotetext{
7 "el hedonismo en general de clases altas europeas, la permisividad de sus vinculaciones sociales, que iba desde participar en las fiestas rufianescas de los maquereaux hasta el consumo de drogas, junto con el refinamento artístico y cultural de la capital francesa, atrajeron la visita o la estadía de restacueros y otros personajes porteños en búsqueda de adquirir una pátina de distinción y superioridade" (RAPOPORT E SEOANE, 2007, p. 377).
} 
Viñas, é possível observar essas viagens a partir de seu sentido geracional, olhar que, neste trabalho, ajuda a alocar a direção e a motivação dessas viagens como sismógrafos do aggiornamento simbólico que marca as primeiras décadas do século:

Com a consolidação do grupo social dirigente a partir de 1880, a viagem pela Europa se institucionaliza: nem pioneiros nem precursores ou aventureiros, aqueles que a celebram adotam cada vez mais um ar oficial e o itinerário se torna ritual. Viaja-se para a Europa para se santificar e voltar consagrado; as preocupações empíricas sobre o próprio país vão se diluindo para serem substituídas por um movimento de entonação mística: o Gentleman viajante é liberado de seu país, a Argentina ou Buenos Aires são matéria desprezível, o corpo do pecado ou o mal, e disso é preciso purgar-se através da iluminação que emerge do empírico europeu. A permanência ali, a permanência mais longa no seio do absoluto, facilita a impregnação e a unidade do viajante espiritual argentino com o espírito europeu. Na verdade, a etapa da viagem bumerangue é inaugurada: importa menos ir do que voltar. O paraíso está lá, mas a verificação do sagrado é dada aqui (...). Em alguns casos, o retorno da Europa não implica apenas a consagração como argentino de primeira classe, mas também a identificação com o estrangeiro. $\mathrm{O}$ cavalheiro que viajou para a Europa vê seu próprio país com um olhar europeu: ‘Tudo parecia primitivo e distante como uma coisa do Extremo Oriente - confessa Daniel García Mansilla em suas memórias -. No entanto, pouco a pouco fui aclimatando-me ao ritmo da vida e costumes, assim como às pessoas; todos eram geralmente abertos, bem-humorados e compreensivos, embora algumas vezes fossem bastante zombeteiros, como se fossem crianças malcriadas'. A viagem sacramentada se sobrepõe à viagem imperial: o argentino santificado na Europa internalizou a perspectiva central e olha seu país e seus compatriotas como o funcionário colonial se enfrenta com os nativos. (VIÑAS, 2005, p. 43-45, tradução nossa) ${ }^{8}$

O recurso ao texto de Viñas ajuda a perceber de que forma, a partir dessas viagens, os padrões de consumo e, notadamente, de consumo intelec-

\footnotetext{
8 "Con la solidificación del grupo social que dirige al país luego de 1880, el viaje europeo se institucionaliza: ni pioneros, ni precursores, ni aventureros, quienes lo celebran adoptan cada vez más el aire de oficiantes y el itinerario se convierte en ritual. Se viaja a Europa para santificarse allá y regresar consagrado; las preocupaciones empíricas por el propio país se van diluyendo para ser reemplazadas por un movimiento de entonación mística: el gentlemán viajero se libera de su país, la Argentina o Buenos Aires son la materia desdeñable, el cuerpo pecaminoso o el mal, y de eso hay que purgarse a través de la iluminación que desciende desde el empíreo europeo. La estada allá, la permanencia más prolongada en el seno de lo absoluto, facilitan la im pregnación y la unidad del espiritual viajero argentino con el espíritu europeo. En realidad, se inaugura la etapa del viaje bumerang: no interesa tanto ir porque se va para volver. El cielo reside allá, pero la verificación de la sacralidad se da aquí. (...) En algunos casos cuminan tes el regreso de Europa no sólo implica la consagración en tanto ar-
} 
tual, são elevados a substitutos das formações técnicas e profissionalizantes passíveis de serem adquiridas na nascente universidade portenha. Nesse sentido, a viagem de formação, mesmo quando entendida a partir da chave do lazer, é o que viabilizava a aquisição de um senso prático, de um sentido do jogo, no sentido formulado por Bourdieu (2010), que aproximava os hábitos e a sociabilidade da elite portenha à sua congênere parisiense.

Neste momento, faz-se necessária uma pequena incursão nesse universo francês que informava os letrados argentinos, na medida em que ele também estava, como todos os outros campos nacionais, inscrito em determinadas dinâmicas contingentes do prestígio culto internacional. Como sugere Casanova (2002a), a história da "república mundial das letras" é uma história de tensões, não uma equação simples que poderia ser descrita através da associação causal entre polo político e econômico dominante e polo intelectual dominante. Se consideramos que a legitimidade do capital literário parte de que "todos os jogadores tem em comum a crença na mesma aposta que nem todos fizeram, ou pelo menos não no mesmo grau, mas por cuja posse todos lutarão" (CASANOVA, 2002a, p. 32), é preciso que o fascínio exercido pelo universo letrado francês sobre as elites argentinas não escamoteie fatores como a antiguidade dos clássicos, o prestígio do idioma de Valéry e, ainda, as propriedades sociais dos intermediadores entre os dois campos nacionais.

Lewis Coser (1968), ao descrever o funcionamento dos salões na sociedade francesa, ainda no século XVIII, ilustra a sociabilidade que pretendo rastrear. Espaços de arbítrio do gosto e do reconhecimento intelectual, os salões eram menos formais que a corte oficial, muito embora repletos de instrumentos de hierarquização. Nesses 'espaços de arbítrio do gosto', lembra Casanova (2002a), uma série de intelectuais e artistas latino-americanos puderam dizer, abertamente, que se descobriram americanos em Paris. Mesmo escrever as correspondências pessoais em francês, por exemplo, ajudava

\footnotetext{
gentino de primera clase, sino también la identificación con el europeo. El gentleman que ha viajado a Europa contempla a su propio país con mirada europea: "Todo me parecía primitivo y distante como cosa del Lejano Oriente - confiesa Daniel García Mansilla en sus memorias -. Sin embargo, poco a poco me fui aclimatando al ritmo de la vida y a las costumbres, así como a las gentes; todos se mostraban en general abiertos, bonachones y comprensivos, aunque a veces bastante burlones, cual si fueran niños traviesos". En esta coyuntura el viaje sacramentado se superpone con el viaje imperial: el argentino santificado en Europa ha internalizado la perspectiva central y mira a su país y a sus comptriotas como el funcionario colonial se enfrenta con los naturales" (VIÑAS, 2005, p. 43-45).
} 
esses letrados periféricos a se projetarem no centro, tendo em vista que já no século XVIII a língua francesa impõe seu uso transnacional, muito por conta do processo de laicização das referências letradas que começaram naquela sociedade (HEILBRON; SAPIRO, 2002; MILO, 1984). Apesar da rivalidade inicial pelo predomínio da consagração letrada com a Inglaterra, é apenas a referência alemã, em meio ao século XIX, que questionará (não questionará) o paradigma francês. De qualquer modo, obter a aprovação de Paris foi importante até avançadas décadas do século XX, motivo pelo qual não é acessória a reiterada associação de prestígio que os intelectuais argentinos executam em relação aos cânones parisienses (CASANOVAa, 2002).

Heilbron (1995), analisando a composição desse cânone, pontua que, ao contrário de países como a Alemanha, no caso francês as Academias privadas foram mais capazes que as universidades de angariar alguma autonomia frente à Igreja e, posteriormente, ao Estado. Esse tipo de configuração, como é patente no caso argentino, favorece uma lógica de recrutamento menos burocrática e, ao mesmo tempo, mais tradicional, fundamentada nas relações familiares e no compartilhamento de um estilo de vida, de uma atitude diante das coisas do pensamento. Essa peculiaridade francesa - o vigor da esfera privada em relação ao ensino formal - é também abordada por C. Charle, em sua análise sobre a formação do universo intelectual europeu (1994; 1996). Durante a primeira metade do século XIX, segundo o autor, os polos de atração eram Paris, Londres e Bruxelas. Ao contrário das últimas, Paris oferecia condições de vida aos intelectuais imigrantes, justamente por dispor de postos de trabalho e colocações sociais menos burocratizadas que os outros países, especialmente na imprensa, mas também nos liceus e escolas recém-fundados.9 O vigor do campo privado, nesse sentido, favorecia a diversificação das possibilidades intelectuais, a ponto de que

\footnotetext{
9 Charle afirma que "A modificação das representações sociais dos intelectuais em diferentes países e a evolução de suas formas de intervenção social e política provêm, em grande parte, de mudanças morfológicas e sociológicas anteriores, mas também de mudanças significativas na cronologia da liberalização da vida pública" (CHARLE, 1996, p. 243, tradução nossa). ["La modification des représentations sociales des intellectuels dans les différents pays et l'evolution de leurs formes d'intervention sociale et politique découlent en grande partie des changements morphologiques et sociologiques précédents mais aussi des décalages sensibles dans la chronologie de la libéralisation de la vie publique" (CHARLE, 1996, p. 243)]. Os combates pela liberdade e pela autonomia passam a ser a tônica do debate no campo, especialmente nos países liberais como a França. "Ele separa aqueles que, em função de uma antiga imagem elitista, se manifestam contra a modernidade e a democracia ou recusam o engajamento em nome da autonomia e aqueles que rompem essas três normas em nome de um prolongamento
} 
A oposição entre um discurso profissional - do tipo inglês - e um discurso muito mais social e político - do tipo continental - resume bastante bem a clivagem entre uma Europa onde as profissões intelectuais permanecem amplamente pensadas em relação ao Estado ou às universidades - daí um problema de possível regularização voluntária - e uma Europa onde o mercado e a competição individual servem como um mecanismo regulador anônimo, apesar de suas desvantagens sociais. (CHARLE, 1996, p. 175) ${ }^{10}$

Enquanto a Alemanha apresentava-se como uma meca científica, que atraia jovens do mundo todo para receberem treinamento em seus famosos seminários, a França oferecia uma possibilidade de formação muito além da estatutária: tratava-se, como Bourdieu sugere n'A Distinção (2010), de um aprendizado de maneiras. O aprendizado do idioma, dos modos e do gosto aparece, desse modo, como afirmação prática da diferença. O gosto que não se discute, que se reivindica fundado pela natureza, torna-se mais prestigioso, num universo tão carente de prestígio para as instituições educativas como era a Argentina, do que o gosto adquirido de modo formal. A frequência aos salões franceses, desse modo, facultava às elites argentinas a prerrogativa da ousadia intelectual e dos investimentos mais arriscados, em relação àquele setor que, incorporando-se recentemente ao ensino formal, dependia exclusivamente de sua formação escolar (BOURDIEU, 2010, 2013).

A competência cultural é definida por suas condições de aquisição. No caso do recorte desta investigação, são sintomáticas as viagens de formação do gosto que empreendiam os filhos de famílias abastadas de Buenos Aires, como os Ocampo, os Anchorena, os Casares, os Alvear, dentre outros. O saber

\footnotetext{
do combate pela liberdade e que se inquietam diante da força persistente da reação ou das regressões racistas e nacionalistas" (CHARLE, 1996, p. 245, tradução nossa). ["El separe ceux qui, en fonction d'une image élitiste ancienne, se méfient de la modernité et de la démocratie ou refusent l'engagement au nom de l'autonomie et ceux qui violent dans ces trois terms un prolongement du combat pour la liberte et s'inquiètent de la force persistante de la réaction ou des régressions racistes et nacionalistes" (CHARLE, 1996, p. 245)]. Na França, essa dicotomia é representada pelo caso Dreyfus. Na Alemanha se define negativamente: coexistência de "um alto grau de autonomia sem a reivindicação majoritária de poder trabalhar fora da jurisdição específica" (CHARLE, 1996, p. 245, tradução nossa). ["un haut degré d'autonomie sans revendication majoritaire d'um pouvouir hors du chamo de compétence specifique" (CHARLE, 1996, p. 246)].

10 "L'opposition entre un discours professionnel - de type anglais - et un discours beaucoup plus social et politique - de type continental - résume assez bien le clivage entre une Europe où les professions intellectuelles restent en grande partie pensées par rapport à l'État ou aux universités - d'où un problème de régularion volontaire éventuel - et une Europe où le marché et la concurrence individuelle servente de mécanisme régulateur anonyme malgré leurs inconvenientes sociaux" (CHARLE, 1996, p. 175).
} 
e o habitus cultivado, para esse setor, é produto de uma lenta familiarização. A partir da distinção de Bourdieu entre doutos e mundanos, é importante considerar que, se o capital estatutário de origem e a precocidade, são frutos de séculos de acumulação de tempo de acesso, não parece coincidência que as viagens de formação de gosto pela Europa aumentem - e, seguindo Viñas, tornem-se estéticas e místicas - conforme a burguesia enriquecida aumenta as pressões por acesso aos meios educacionais formais. Se, portanto, os filhos da burguesia pressionam o sistema universitário argentino e, inclusive, o modelam segundo suas necessidades, as fronteiras distintivas são reorganizadas diante da posse desse savoir faire adquirido no exterior, notadamente em Paris.

\section{De Berlim a Buenos Aires através de Madri}

As filiações intelectuais e artísticas descritas acima respondiam, alusivamente, ao clima progressista e modernizante que caracterizou a geração da virada do século e do Centenário em 1910. Se a sociabilidade das consagrações culturais ganhava novas dimensões a partir de uma nova concepção do espaço público, como salienta Sarlo (1997, 2011), há também uma dimensão menos evidente desses dispositivos. As grandes fortunas das famílias criollas, na ausência de uma rede pública de financiamento (MICELI, 2014), viabilizaram o amplo circuito editorial que então começa a despontar numa Buenos Aires com cada vez mais leitores. Isso solidifica as próprias relações sociais envolvidas no universo das letras, na medida em que as relações de mecenato, baseadas em acordos informais e de prestígio familiar, também mantém fechadas, aos imigrantes, os principais espaços de sociabilização. Num universo intelectual onde, nos termos de Miguel Cané, o incentivo à cultura era quase nulo, aumentam exponencialmente as prerrogativas das instâncias privadas, como os cafés e, sobretudo, as revistas e espaços culturais de encontro, como o Jockey Club.

Essa sociabilidade, favorecida pelos intentos modernizadores da época de Alvear, se gesta ainda na época de Rosas. Quando de seus decretos em prejuízo da universidade, sugere Vicente Quesada, ocorre um esvaziamento da incipiente instituição, "de maneira que a juventude de minha época não tinha meios para instruir-se, nem estímulos para aprender; mas como não quis se resignar à ignorância, lutou e se instruiu como pôde, desenvolvendo-se com mais pujança a iniciativa pessoal e o caráter de cada um" (1942, 
p. 127). ${ }^{11}$ As tertúlias nos salões da classe alta, ${ }^{12}$ como eram chamadas essas reuniões, aconteciam principalmente em casas de hóspedes da Academia de Jurisprudencia, para onde confluíam nomes como Manuel Ugarte, Vicente Quesada, Eseubio Ocampo e Juan O. Garcia. Caracterizando-as, segue Quesada, "ali se conversava de literatura, de política, de administração, mas não foi um círculo político, pois todos ali viviam retirados das agitações dos partidos" (1946, p. 164). ${ }^{13}$

Essa atmosfera permanece operante e ganha força, como dito anteriormente, na geração da virada do século. Na última década do XIX e na primeira do século $X X$, paralelamente às contendas entre positivistas e espiritualistas, aos debates sobre a consolidação da Universidade de Buenos Aires e à Reforma de Córdoba, é possível localizar um esforço exemplar do intendente Torcuato de Alvear: trata-se de europeizar a cidade, habilitando-a para uma nova modalidade de ocupação do espaço público e, principalmente, para a circulação de uma sociabilidade letrada em ascensão. ${ }^{14}$ A abertura da Avenida de Mayo - o boulevard parisiense que se projeta a partir da praça central - e a reforma da Plaza de Mayo, que levou à derrubada da alcova colonial que a dividia, constituem exemplos de uma cidade que pretendia comportar hábitos de vida similares aos parisienses e renderam à Alvear o apelido de "Haussmann portenho". Que nos bairros mais afastados do centro e nos conventillos a situação ainda beirasse a miséria completa (RAPOPORT; SEOANE,

\footnotetext{
11 "de manera que la juventud de mi tempo no tenía médios para instruirse, ni estímulos para aprender; pero como no quiso resignarse a la ignorância, luchó y se instruyó como pudo, desarrollandose com mayor punjanza la iniciativa personal, el caracter de cada uno" (1942, p. 127)

${ }^{12}$ Bourdieu em As regras da arte, define os salões como um tipo de configuração que se distingue mais pelo que exclui do que pelo que inclui (BOURDIEU,1996)

13 "allí se conversaba de literatura, de política y de administración, pero no fue um circulo político, porque todos vivian entonces retirados de las agitaciones de los partidos" (1946, p. 164).

${ }^{14} \mathrm{Na}$ descrição famosa de Romero: “Buenos Aires optou pelas demolições. Federalizada em 1880, Torcuato de Alvear foi designado prefeito pouco depois e pegou na picareta. Foram abaixo a recova vieja que cortava em dois a atual Plaza de Mayo e também boa parte do antigo cabildo colonial para abrir uma avenida que comunicaria aquela praça, onde havia estado o forte e agora se levantava a casa rosada, com a outra praça onde posteriormente foi erguido o monumental Palacio del Congreso. A Avenida de Mayo foi aberta, efetivamente, em pouco tempo e logo ficou totalmente cercada de edifícios modernos, de estilos variados entre os quais não faltavam ousados exemplos de art nouveau. A partir desse momento transformou-se no coração de Buenos Aires. Poucos anos depois, sob a Avenida de Mayo e a rua Rivadavia começou a circular o primeiro trem subterrâneo da América Latina. Não muito depois seriam projetadas duas grandes diagonais que deviam sair da Plaza de Mayo e uma extensa avenida de norte a sul, hoje chamada 9 de Julio. Centenas de casas foram derrubadas para a execução desses projetos" (ROMERO, 1976, p. 311, tradução nossa).
} 
2007), não parecia influenciar decisivamente nessa autoimagem parisiense dos flaneurs de Buenos Aires. Essa atitude, como é de se esperar, não deixava de provocar um desconforto jocoso em alguns setores específicos do universo letrado, notadamente, mas não só, naqueles ligados às demandas dos imigrantes de primeira geração.

Ainda que sem deixar de promover a mudança, os escritos de Miguel Cané, Eduardo Wilde (...) alertam sobre essa nova postura - às vezes uma atitude de parvenu - adotada quase sem digestão. Ridiculariza-se aqueles que voltam da Europa carregados de obras de arte, nem sempre de bom gosto, e aqueles que se debruçam sobre novas regras de etiqueta que se assemelham a manequins de tende. Mas em poucos anos, graças ao seu poder de adaptação, essa elite se afirmou e moveu-se naturalmente nos espaços complexos da nova vida cotidiana. (BRAUN; CACCIATORE, 1996, p. 49, tradução nossa) ${ }^{15}$

Frequentadora dos salões da família Anchorena e ligada aos Alvear, a família Ocampo também compartilhava dessa sociabilidade. Victoria Ocampo testemunha, em sua autobiografia, o estilo de vida típico da elite letrada argentina que venho tentando descrever, notadamente em suas aproximações com a cultura francesa. Vale a pena transcrever algumas passagens exemplares, tanto pela força do texto quanto pela própria posição que Victoria ocuparia nas décadas seguintes. Referindo-se aos preconceitos de classe que percebia em seu cotidiano juvenil, lemos que, apesar de aparecerem entre aspas, se levava muito a sério as tradições nobiliárias argentinas, "isso era bem marcado, apesar da educação estrangeirizante que recebíamos, talvez porque a considerassem, não sem razão, mais refinada" (OCAMPO, 1980, p. 15). ${ }^{16}$ Ocampo descreve uma juventude sob padrões estritamente rígidos, que envolviam um decoro quase colonial: ela e suas irmãs não podiam receber visitas de amigos homens que não fossem da família e, já na adolescência, dançar mais de três músicas com o mesmo par constituía uma séria infração da etiqueta. Sendo mulher numa sociedade como a Buenos Aires

\footnotetext{
15 "Sin dejar de propiciar el cambio, los escritos de Miguel Cané, Eduardo Wilde (...) advierten acerca de esa nueva postura - a veces una actitud de parvenu - adoptada casi sin digerir. Ridicularizan a los que vuelven de Europa cargados de obras de arte, no siempre de buen gusto, y a aquellos que se encorsetean en nuevas reglas de etiqueta que los asemejan a maniquíes de tende. Pero en pocos años, gracias a su poder de adaptación, esa elite se afirmo y se movió con toda naturalidad en los complejos espacios de la nueva vida cotidiana" (BRAUN; CACCIATORE, 1996, p. 49).

16 "esto era ben marcado, apesar de la educación extranjerizante que recibíamos, tal vez por que la consideraban, no sin razón, más refinada" (OCAMPO, 1980, p. 15).
} 
do começo do século, Ocampo não deixa de mencionar o tipo de educação que se ministrava então às moças da aristocracia, o que se tornará, posteriormente, um de seus principais combates enquanto mecenas cultural.

Essa sociabilidade começa a entrar em xeque no fim década de 1920, qualificada por Funes como anos da "erosão do sujeito liberal" (SARLO, 1997; FUNES, 2006). O cosmopolita versado nas artes da conversação parisiense que povoava os cafés de Avenida de Mayo será paulatinamente forçado a conviver com uma outra construção arquetípica, a do homem que está só e espera, na fórmula de Scalabrini Ortiz, de modo que

O cenário das margens já não é mais o lugar literário dos Outros, considerados como pura alienação, como uma ameaça à ordem social, à moralidade estabelecida, à pureza do sangue, aos costumes tradicionais; não é apenas sobre os Outros que devem ser incluídos e redimidos. São outros que podem configurar um Nós com o eu literário de poetas e intelectuais, são outros próximos, quando não são o mesmo. (SARLO, 2010, p. 180)

A ideia de progresso via civilização é abertamente questionada no final da década de 1920. Como mencionado anteriormente, o crescimento descontrolado da cidade, as pressões sociais que advinham do aluvião imigratório (ROMERO, 1976), a crise econômica e, sobretudo, as tensões políticas por abertura do sistema eleitoral, confluíam para que a ideia de "crise" se projetasse, mais uma vez, no horizonte de expectativas intelectuais (ALTAMIRANO, 2009). A mesma ideia de decadência que orientava os debates de espiritualistas como Paul Groussac, se emancipava dos debates teóricos e ganhava as ruas da cidade, os cafés, as universidades e as contendas políticas. Pode-se afirmar, em conformidade com a bibliografia sobre o tema, que, nesse momento, a panaceia positivista de uma sociedade cientificamente orientada para um progresso inefável estava finalmente no passado. A resposta à crise - quando a discussão se torna pública - não passava mais pelas rebuscadas elucubrações saintsimonianas; tratava-se, ao contrário, de encontrar uma resposta funcional para a crise, de levar a cabo uma revisão. As chaves dessa equação passaram a ser buscadas no passado argentino por um amplo setor intelectual que amadurece nesse momento, o dos imigrantes de primeira e segunda geração.

O tema das gerações, nesse sentido, emerge com dupla significação: por um lado como poderosa autoidentificação da comunidade imigrante que, pressionando os circuitos culturais da elite criolla, formula suas demandas simbólicas por integração. Por outro ponto de vista, tematicamente, é um dos pontos nevrálgicos de certa "atitude alemã" que passa a predominar nesses comportamentos intelectuais emergentes. Vale lembrar que, desde a década 
de 1910, a Alemanha era a referência institucional de uma parte importante do campo letrado argentino, e o modelo de universidade baseado na "figura do sábio", oposto, em sua mística, ao diletante francês, já atraia partes importantes dos letrados de Buenos Aires. Um exemplo da circulação dessa "atitude" ou desse "estilo" pode ser encontrado nos relatórios de exploração de Ernesto Quesada, professor de Sociologia da UBA (1906), quando de sua viagem a Alemanha. ${ }^{17} \mathrm{O}$ ponto de partida do relatório, que também funciona como justificativa, é a hegemonia mundial da universidade alemã:

A erudição alemã merece a reputação de superioridade de que desfruta; os alemães são uma grande parte dos pioneiros que, pelo aperfeiçoamento de métodos e por descobrimentos fundamentais, abriram novos horizontes para a ciência; e desde que os métodos históricos, alçados ao mais alto grau de perfeição, eficiência e elegia, foram universalizados e que os horizontes das disciplinas históricas foram delimitados, a Alemanha espalhou, em todos os domínios por explorar, inumeráveis trabalhadores, industriosos, disciplinados, exatos, capazes e satisfeitos em praticar desinteressadamente os questionamentos mais abstrusos. (QUESADA, 1910, XV apud TEDESCO, 2018, tradução nossa) ${ }^{18}$

O "estilo" alemão atraia, em suma, pelo questionamento do estilo livresco, creditado às licenciosidades da tradição anglo-francesa. Nesse sentido, encontrando solo fértil em uma Argentina carente de plataformas de integração, a substituição do universalismo francês (e de sua atitude cosmopolita) por uma atitude enraizada, o modelo de intelectual alemão, funciona como paradigma para as gerações desiludidas com as promessas do Centenário. Nesse sentido, vale a pena acompanhar a circulação do pensamento de Ortega y Gasset. Embora espanhol, Ortega foi grande divulgador de certa "visão de mundo alemã", e ajuda a entender de que modo a continuidade patrimonial que então se estabelecia com a Espanha redundava em uma divulgação da "atitude germânica" diante das coisas do pensamento.

Desde as já bastante conhecidas meditações orteguianas que circulam entre os intelectuais argentinos, passando pelas leituras nacionalistas de al-

\footnotetext{
${ }^{17}$ O tema foi tratado por mim em artigo publicado em 2018, conforme bibliografia. (Tedesco, 2018).

18 "La erudición alemana ha merecido la reputación de superioridad de que goza; alemanes son una gran parte de los iniciadores que, por el perfeccionamento de los métodos y por descobrimentos fundamentales, han abierto a la ciência nuevos horizontes; y desde que los métodos históricos, llegados al más alto grado de perfección, eficácia y elegância, se hán universalizado y que los horizontes de las disciplinas históricas se han delimitado, Alemania há desparramado, en todos los domínios a explorar, innumerables trabajadores, laboriosos, disciplinados, exactos, capaces y satisfechos de practicar desinteressadamente las más abstrusas indagaciones" (QUESADA, 1910, XV apud TEDESCO, 2018).
} 
guns setores, até o sentimento anti-imperialista que ganha terreno a partir da divulgação de Ariel, de Rodó, a aproximação com a Espanha é um dado fundamental na equação das referências intelectuais argentinas (SVAMPA, 1994). Guillermo del Torre sintetiza, em Madrid, Meridiano Intelectual, essa posição. No texto, publicado em 1927, ele advoga que não se deveria falar em América Latina, mas em Iberoamerica, Hispanoamerica ou mesmo América Espanhola, afinal, sustenta, toda a cultura e valores "que não sejam espanhóis serão autóctones, aborígenas, mas de nenhum modo franceses, italianos ou saxões"19 (DE TORRE, 1927, p. 1, tradução nossa). O latinismo seria, pois, uma abertura perigosa às pretensões imperialistas inglesas e francesas, em seus termos: "Basta de tolerar passivamente essa capitulação de nosso prestígio, esse desvio constante dos interesses intelectuais hispano-americanos em direção à França" (DE TORRE, 1927, p. 1, tradução nossa). ${ }^{20}$ Reafirmar a Espanha, nesse caso, seria reivindicar uma aliança onde não há dominação intelectual, mas colaboração.

Efeito prático dessa aproximação, como demonstra Beired (2009), é a criação de uma série de redes entre intelectuais espanhóis e argentinos, englobando a fundação de centros de pesquisa e a concessão de bolsas de estudo pelo governo espanhol, medidas que estimulavam o movimento de regeneração espanhola em oposição às potências liberais daquele contexto.

No final do século XIX, o interesse pela América foi uma das molas mestras do regeneracionismo, movimento de ideias cujos membros se debateram por encontrar a chave para a compreensão da crise da Espanha, identificada como um processo estrutural de decadência que poderia ser revertido mediante o estabelecimento de novos laços com as ex-colônias. (BEIRED, 2009, p. 45)

Recuperar a essência argentina ou "a honra bárbara", como queria Ramos Mejía, através de uma operação intelectual hostil ao universalismo francês e avessa às abstrações: essa poderia ser a síntese da plataforma que orienta os intelectuais nacionalistas revisionistas da década de 1930. Centrados na composição da figura do gaúcho - e da associação, muitas vezes excêntrica, entre o morador dos pampas e o paiador espanhol - esses autores promoveram a busca pelos elementos autóctones, comunitários e religiosos, capazes de

\footnotetext{
19 "que no sean españoles serán autóctonos, aborígenes, pero em modo alguno, franceses, italianos o sajones" (DE TORRE, 1927, p. 1).

20 "'Basta de tolerar passivamente esa merma de nuestro prestígio, esa desviación constante de los intereses intelectuales hispano-americanos hasta Francia" (DE TORRE, 1927, p. 1).
} 
restabelecer os vínculos que se percebiam dissolvidos na Babel portenha (SVAMPA, 1994). O elogio do campo, sobretudo, dava-se em oposição à cidade, ao território do flaneur por excelência. A etiqueta e o pedantismo, arquetípicos do mundo letrado argentino até então, passaram a ser associados à decadente classe aristocrata que, além de ociosa, representava interesses estrangeiros e, portanto, danosos à nação argentina.

Nesse contexto, tanto a figura do sábio espiritualista desinteressado quanto a do cientista positivista são substituídas por uma militância assertiva em prol da pátria, do idioma, da cultura nacional. Somada à essa demanda interior ao campo argentino, é possível adicionar o alerta de Rolland de que "após a guerra, a república de Weimar mantém uma ativa propaganda anti-francesa na américa latina" (ROLLAND, 2004, p. 278). O recurso à continuidade patrimonial com a Espanha também engendra um elemento de segunda ordem que seria fundamental para as análises subsequentes: na mesma medida em que os revisionistas invocavam a tradição espanhola, os revisionistas espanhóis reivindicavam, não menos, a tradição alemã.

Exemplarmente, pode-se partir da fala de Simmel que diagnostica, no flaneur de Paris, diversas camadas de ansiedade. O típico blasé, segue ele, que já viu tanta coisa que não se choca com mais nada, tem os sentidos progressivamente embotados pela grande cidade. Simmel, um dos grandes formuladores da literatura de catástrofe que organizava o trânsito entre Alemanha e Espanha, foi professor de Ortega, o pensador espanhol que inspirou não poucas gerações de intelectuais argentinos. Ortega, tal como muitos coetâneos, empenhava-se em dar uma resposta ao "imperativo da modernidade", grande tópico dos seminários de Simmel, dos quais era assíduo frequentador. A aposta de Ortega condensa-se num apelo à "regeneração espanhola", solução bastante prototípica para o tema da crise e reveladora de um modo específico de experienciar e organizar a experiência do tempo (HARTOG, 2014; KOSELLECK, 2006).

Ortega frequentou, como detalha Gil Villegas (1998), todo o circuito da universidade alemã que, na virada do século XIX para o XX, foi a grande aglutinadora dos debates acadêmicos europeus, especialmente os filosóficos. Professor de Ortega, Simmel foi um dos formuladores da versão trágica do desencantamento do mundo, pauta que também perpassava, naquele universo, as discussões de professores como Max Weber e, tangencialmente, Martin Heidegger, de quem Ortega foi aluno. Gabriel Cohn analisa a vinculação de Georg Simmel à tradição do conservadorismo historicista alemão, de modo a alocá-lo, inclusive, como um dos continuadores da divisão diltheana entre ciências da natureza e ciências do espírito. Nos termos de Cohn 
Seu ponto de partida é a ideia de vida, como fluxo concreto de eventos dotado de caráter intrinsecamente criador, cujos portadores são sempre indivíduos (mas não subjetividades autônomas, posto que imbricados num transcurso que os ultrapassa), contraposta a qualquer concepção que separe os conteídos normativos e a existência concreta. (COHN, 2003, p. 55)

As três maiores universidades alemãs de então, nas quais se gestava essa concepção específica sobre a crise e a decadência do ocidente, eram Heidelberg, onde estava Lukács, Marburgo, para onde vai Ortega, e Friburgo, onde lecionava o autor de Ser e Tempo. São essas as referências, salienta Villegas, que ajudam o filósofo espanhol a desenvolver sua própria versão do "imperativo" simmeliano: "Ante a crise produzida pela objetivação da cultura, Ortega propõe uma revitalização radical para promover um novo tipo de cultura baseada na espontaneidade" (GIL VILLEGAS, 1998, p. 174, tradução nossa). ${ }^{21}$ Essa "revitalização" vem se constituir como a categoria central do projeto intelectual de Ortega, a saber, encontrar, na cultura alemã, uma possibilidade de reestruturação para seu país, uma sorte de germanização da tradição espanhola que operaria, em seus termos, por afinidade de destino histórico.

O tema da tragédia aparece, em Simmel, já em 1900, na Filosofia do Dinheiro. Nessa obra, a cultura aparece como forma, como síntese do conteúdo da vida. É o século XIX, para ele, que marca o início de um processo de contradição entre vida e forma, desencadeado pela instrumentalidade do dinheiro. "Essa é a origem da situação problemática do homem moderno: ele se sente cercado por um mundo infinito de elementos culturais que não são desprovidos de importância para ele e que, no entanto, não têm uma importância decisiva" (SIMMEL, 1900, apud VILLEGAS, 1998, p. 158, tradução nossa). ${ }^{22} \mathrm{O}$ homem desencantado de Simmel é similar ao boêmio parisiense: tem tudo e não possui nada, está desenraizado e caminha aleatoriamente pela cidade. A valoração desse estilo de vida, contudo, é francamente invertida. A exterioridade aparece, já nesse primeiro Simmel, como atomização. A solução para essa crise do interior, para ele, não radica nos dispositivos da modernidade em si, mas em uma "vontade de humanidade": "A própria

\footnotetext{
21 “ante la crisis producida por la objetivación de la cultura, Ortega propone una revitalización radical para fomentar um nuevo tipo de cultura fundamentada em la espontaneidad" (GIL VILLEGAS, 1998, p. 174).

22 “Así se origina la problemática situación del hombre moderno: se siente rodeado por un mundo infinito de elementos culturales que no dejan de tener importância para él, y que sin embargo tampoco tienen una decisiva importância" (SIMMEL, 1900, apud VILLEGAS, 1998, p. 158).
} 
reificação da cultura objetivada possibilita ao indivíduo criar uma esfera de interioridade para realizar seu próprio desenvolvimento individual" (SIMMEL, 1900, apud VILLEGAS, 1998, p. 159, tradução nossa). ${ }^{23}$ É a essa tradição de "vontade da humanidade" que se filiaria Ortega, alocando-a, ao longo do desenvolvimento de sua obra, em um quadrante geracional.

A influência de Ortega na América Latina e na Argentina, especificamente, onde viveu, em períodos alternados, entre 1936 e 1942, é bastante conhecida. Abellan (1967) localiza a influência do pensador espanhol em duas gerações latino-americanas. Inicialmente a de 1915, que inclui nomes como Alfonso Reyes, Coroliano Alberini e Haya de la Torre e que foi responsável pela normatização da filosofia através da cultura em termos continentais. Essa primeira onda de recepção marca, é importante salientar, a difusão do pensamento perspectivista-circunstancialista, que tanta utilidade terá ao fornecer, aos quadros intelectuais nacionalistas, um referencial antipositivista que reiterava a autenticidade da cultura latino-americana a partir de uma perspectiva histórica (RUVITUSO, 2015). A busca pelo eu-coletivo geracional inspirado em Ortega alçou a discussão vitalista e identitária a dimensões continentais, como é o caso da Raza Cósmica de Vasconcellos, por exemplo. Uma segunda geração de leitores de Ortega, especialmente na Argentina, surge a partir de 1930, justamente no momento de amadurecimento das concepções nacionalistas. Raul Orgaz, por exemplo, é testemunha nesse contexto do impacto das meditações do filósofo espanhol, notadamente a partir da publicação, em 1927, de El Tema de Nuestro Tiempo. Em paralelo, podemos encontrar Carlos Astrada que, também a partir da leitura de Ortega, combinada com leituras do existencialismo alemão, formula as sofisticadas plataformas antipositivistas e anticosmopolitas que informarão as discussões públicas sobre o "ser nacional".

Em El Tema de Nuestro Tiempo, de 1923, Ortega desenvolve a ideia de geração enquanto variação da sensibilidade vital, pulsação de potência orgânica. Na medida em que as gerações históricas aparecem enquanto unidades espirituais, torna-se plausível interpretar a solução para "a crise da modernidade" em termos de destino comunitário e, em leituras mais radicais, como as do próprio Leopoldo Lugones, como "missão". Diagnosticando uma Espanha "carente de corações de vanguarda" Ortega fornecia, para as demandas

\footnotetext{
23 “la reificación misma de la cultura objetivada posibilita al indivíduo la creación de una esfera de interioridad para realizar su próprio desarrollo individual" (SIMMEL, 1900, apud VILLEGAS, 1998, p. 159).
} 
simbólicas do nacionalismo argentino, uma potente justificativa teórica ao colocar em circulação o repertório de matiz diltheana que Gabriel Cohn caracterizou como a "captação, por processos irredutíveis à razão analítica, de totalidades históricas singulares e concretas, de cujo caráter orgânico o próprio estudioso é participante" (COHN, 2003, p. 14). As transformações políticas e econômicas são menos profundas que as das ideias, alegava Ortega, e a especificidade geracional deveria ser radicada nesse segundo nível, na medida em que se tratava, sobretudo, de uma "sensibilidade". Nos termos de Ortega, "o caráter ativo, criador da personalidade é, em efeito, demasiado evidente para que possa aceitar-se a imagem coletivista da história" (ORTEGA Y GASSET, 1956, p. 6, tradução nossa). ${ }^{24}$

As gerações possuem, nesse ponto de vista, sua própria unidade histórica. Há aquelas acomodadas e as combativas, cada uma delas portadora de uma missão. Na medida em que essa unidade se define pelos "princípios do sentir" e não por adesões políticas, posicionar-se no seu tempo, circunstanciar-se, equivalia a enfrentar as demandas históricas que se apresentavam à cada unidade espiritual e, desse modo, a comprometer-se. Entre essa posição e a de Lugones - para Valdéz (2000) uma composição sui generis de militarismo germânico e aristocratismo espanhol - que convoca ao combate em La hora de la espada, pode-se transitar com relativa facilidade, como o demonstram as múltiplas reivindicações de Ortega pelos nacionalistas e revisionistas argentinos. O diagnóstico de tragédia e de crise está implícito nessa retórica combativa inspirada no regeneracionismo de Ortega, e a terapia, compartilhada nos dois lados do Atlântico, passava pela volta à espontaneidade: "a razão pura tem que ceder seu império à razão vital" (ORTEGA Y GASSET, 1956, p. 59, tradução nossa). ${ }^{25}$ É possível notar em que grau as teses de Ortega puderam se converter numa consígnea nacionalista a partir da funcionalidade da crítica ao tecnicismo que sobrevém do vitalismo de Ortega. A técnica, a modernidade, a dissolução dos costumes, o dândi embotado simmeliano, a perda dos vínculos pátrios: todo o arcabouço temático do revisionismo nacionalista argentino poderia ser condensado nesse enfrentamento entre a cultura científica e sua reação vitalista. ${ }^{26}$

\footnotetext{
24 "el caracter activo, criador de la personalidad, es, en efecto, demasiado evidente para que pueda aceptarse la imagen colectivista de la historia" (ORTEGA Y GASSET, 1956, p. 6).

25 “la razón pura tiene que ceder su império a la razón vital" (ORTEGA, 1956, p. 59).

${ }^{26}$ Em Meditaciones del Quijote, definido pelo autor como ensaios de amor intelectual, Ortega pretende superar o caráter essencialmente político do XIX, "a vida intelectual foi relegada, como se fosse uma questão pouco séria e não transcendente” (1914, p. 26) [“la vida individual
} 
A leitura de Ortega, ainda, localizava na revolução francesa a "origem do mundo hostil", mundo da rebelião das massas que, na leitura dos nacionalistas argentinos, se impunha nas ruas de Buenos Aires. Mais uma vez, as fronteiras distintivas entre elites e imigrantes se interpõem nas possibilidades teóricas dos discursos. A proposta de Ortega de que "as coisas precisam se reencontrar com seu destino" supõe, por definição, a pergunta sobre qual seria esse destino. Dirimidas as expectativas modernizadoras do centenário, bem como toda confiança científica em um mundo racional e emancipado, a pergunta pelo destino histórico é formulada, na Argentina dos anos 1930, como um retorno à essência.

Os maiores veículos de publicação de Ortega são a revista Sur, o Circulo de las Artes e o jornal La Nación, polos consagrados do campo intelectual nas décadas de 1930 e 1940. É importante, considerar, contudo, que a influência de Ortega ultrapassou em muito os círculos aristocratas aos quais inicialmente se filiou. Se pensarmos, a partir de Heilbron e Sapiro (2002), que as dinâmicas de recepção respondem sempre a demandas do contexto de aclimatação dos discursos, a relação entre a formulação circunstancialista de Ortega e os revisionistas argentinos torna-se mais cristalina, inclusive, que aquela inicialmente baseada num compartilhamento de ethos, que Ortega estabeleceu, por exemplo, com o círculo de Victoria Ocampo. O trânsito de Ortega na Argentina é, como tento indicar, híbrido. Escutado em conferências na Universidade de Buenos Aires, publicado pelo jornal de maior circulação no país e difundido através de leituras nacionalistas, é no âmbito editorial que suas teses ganham maior repercussão e expressam, com mais nitidez, seu apego às referências alemãs.

Sua Revista de Occidente, que começa a ser publicada em Madri em 1923, é uma das inspirações para a Sur, relação testemunhada na extensa troca de cartas entre Ortega e Victoria Ocampo, bem como nas memórias da diretora da Sur sobre o tempo que Ortega passou na Argentina a seu convite. Já

quedó relegada, como si fuera cuestión poco série e intranscendente" $(1914,26)]$. A proposta é colocar a Espanha à altura dos tempos já que quem não tem a experiência do profundo aplaude a mediocridade (68). A meditação, esse esforço doloroso e integral, não é para todos. Cultura germânica: realidades profundas. Cultura latina: cultura das superfícies. A latinidade, assim, é um pretexto e uma hipocrisia, queremos nos reivindicar herdeiros do espírito helênico. O mediterrâneo é uma justificativa para a sensualidade, fugacidade, para a não-percepção. Espanhóis produzem sempre do caso, tem uma espécie de "síndrome de Adão". Por que o Espanhol se obstina em viver anacronicamente, em vez de assumir sua parcela da herança germânica, pergunta-se Ortega. Atribuindo essa condição à uma ontologia do povo espanhol, ele responderá que um povo é um estilo de vida e os espanhóis são, por natureza, "espíritos surrealistas". 
no segundo número da revista, de 1924, encontramos um texto de Ortega sobre Kant e um de Pio Barojo, intitulado Divagaciones de auto-crítica, sobre a geração de 1898. Em 1929 a revista publica o primeiro romance de Ocampo De Francesca a Beatrice e um famoso texto de Simmel, Filosofia de la Coquetería. Em abril de 1932 há uma homenagem ao centenário de Goethe, encabeçada por um texto de Ortega paradigmaticamente intitulado Pidiendo Goethe desde adentro. Carta a un alemán. Nesse texto, lemos uma filiação explícita de Ortega, num tom similar àquele devotado, no La Nación, à cultura argentina: "Devo enormemente à filosofia alemã e espero que ninguém me escamoteie o reconhecimento de ter imprimido a meu trabalho, como uma de suas facetas principais, a tarefa de aumentar a mente espanhola com a torrente do tesouro intelectual alemão" (ORTEGA Y GASSET, 1983, p. 16, tradução nossa). ${ }^{27}$ A Revista de Occidente publica, dentre outros, Fichte, Kant, Hegel, Scheller, Keysering, Husserl, Simmel, Jung, Dilthey, Buckhardt e Heine, além de repercutir a literatura de crise que ganhará tanto destaque entre os correligionários argentinos, notadamente a partir das traduções e comentários críticos à obra de Oswald Spengler (BRINKMANN, 2014).

Para San Martín (1994), o tributo que a filosofia de Ortega presta a tradição alemã, que tão frequentemente aparece nas escolhas editoriais da Revista de Occidente, encontra-se no cerne de sua participação na geração regeneracionista espanhola:

Porque o problema da Espanha é ter ficado congelada no começo da Idade Moderna, não ter adotado a modernidade, mais ainda, ter trabalhado reativamente contra ela, rejeitando a necessidade de teoria, a necessidade de ciência, da razão, com que a razão supõe a sujeição do indivíduo aos critérios de tudo e educando-se para a imoralidade. Bem, existem os dois males seculares da Espanha, falta de ciência e falta de moralidade. (SAN MARTÍN, 1994, p. 23, tradução nossa) ${ }^{28}$

\footnotetext{
27 “Debo enormemente a la filosofia alemana y espero que nadie me escatimaria el reconocimiento de haber dado a mi labor, como una de sus facciones principales, la de aumentar la mente española con el torrente del tesoro intelectual germânico" (ORTEGA Y GASSET, 1983, p. 16). 28 "Porque el problema de España es haber quedado congelada en el comienzo de la Edad Moderna, no haber adoptado la modernidade, más aún, haber trabajado reactivamente contra ella, rechazando la necesidad de la teoria, la necesidad de la ciência, de la razón, con lo que la razón supone de sometimiento de lo individual a los critérios de todo, y educándose para
} 


\section{De Ortega a Ortiz: a geração da crise}

A exposição mais detida de Ortega não objetiva reduzir a ele toda a formulação teórica do nacionalismo argentino. As fontes do movimento são diversas e, eventualmente, contraditórias. Catolicismo, espiritualismo, nacionalismo, historicismo, dentre outras consígneas mobilizadas por autores como Lugones, Palacios etc. não podem ser menosprezadas. ${ }^{29} \mathrm{O}$ ponto em comum entre essas consígneas, contudo, é que se encontravam sustentadas na ideia de crise. Se, nas décadas anteriores, a crise se formulava em termos quase metafísicos pelos espiritualistas contemporâneos de Ingenieros, agora, a tradição antipositivista mobilizada por eles encontrava-se com as demandas simbólicas do movimento nacionalista. A narrativa de crise que sustenta essas teses, ademais, transformava-se no próprio tema das reflexões, ilustrava um mundo onde as fronteiras sociais pareciam ruir, de modo definitivo, diante da afluência das massas à vida política. Nesse sentido, o estilo de vida e a as atitudes intelectuais passam a orbitar em torno de uma figura engajada em seu tempo, circunstancializada, oposta, enfim, à do dândi parisiense que outrora habitava o imaginário intelectual de Buenos Aires.

Conforme se radicalizam esses discursos nacionalistas, cresce em paralelo a hostilidade em relação aos imigrantes mobilizados sindicalmente. A Semana Trágica de $1919^{30}$ marca o início dessa radicalização, a partir da qual o exército - e não mais as elites letradas tradicionais - passaria a ser visto como a "última aristocracia". É esse o contexto da exemplar conclamação de Lugones, em 1924, anunciando la hora de la espada. Em 1927, inspirados por Lugones, um grupo de jovens nacionalistas funda La Nueva Republica, grupo de debate de ideias que se tornará, em pouco tempo, paramilitar. Introduzia-se, através dessa radicalização, um postulado de segunda ordem: a hora da força que se anunciava na proclamação de Lugones era a deixa para substituir o intelectualismo, típico dos setores esclarecidos porteños, por uma reação vital. A razão a serviço da vida, pois, comunga o projeto de Lugones à tradição espiritualista do pensamento alemão e espanhol. Nos termos de Devés

\footnotetext{
la inmoralidad. Pues bien, he ahí los dos males seculares de España, falta de ciência y falta de moral" (SAN MARTÍN, 1994, p. 23).

${ }^{29}$ Para uma análise mais detalhada sobre esse tema é possível consultar a obra de Beired (1996).

${ }^{30}$ Entre 7 e 14 de janeiro, o movimento operário organizado de Buenos Aires sofreu sistemática repressão, o que resultou num massacre de centenas de pessoas em decorrência de uma greve iniciada nos Talleres Vasena.
} 
Valdés, "o iberismo se identifica parcialmente com um certo misticismo ou espiritualismo que atribui à nação um conteúdo que transcende em muito o contratualismo, e a assimila a uma comunidade com sentimentos e ideais comuns" (DEVÉS VALDÉS, 2000, p. 232, tradução nossa). ${ }^{31}$

Leopoldo Lugones, Manuel Ugarte, Ricardo Rojas, Manuel Galvéz. A lista de intelectuais que se colocou nas fronteiras nem sempre estáveis entre revisionismo teórico e militarismo nacionalista é extensa. Filosoficamente, já descontadas as muitas diferenças entre suas leituras, esse grupo se orientava pelo vitalismo em oposição ao positivismo. Bergson, Schopenhauer, e Nietzsche eram mobilizados, a partir da referência de nomes como Ortega, como antídoto ao limitador e proibitivo positivismo. As consígneas teóricas da liberdade criadora, da vida, do amor, da subjetividade, do desinteresse e do espírito aproximam as demandas dos nacionalistas aos temas clássicos dos debates alemães que começavam a circular na Argentina a partir da mediação espanhola. ${ }^{32}$ Nos termos de Valdés,

A partir do positivismo mecanicista era coerente pensar que os povos do nosso continente deveriam seguir o mesmo destino que haviam percorrido os mais modernos. Ao reivindicar, por outro lado, o espiritual, o volitivo, a liberdade criadora, se torna muito

\footnotetext{
31 "el iberismo se identifica parcialmente con un cierto misticismo o espiritualismo que atribuyea la nación un contenido que trasciende en mucho al contractualismo, y la assimila a una comunidade con sentimentos e ideales comunes" (DEVÉS VALDÉS, 2000, p. 232).

32 Para César Graña, esses argumentos ontológicos sobre a América Latina podem ser compreendidos a partir do conceito de "falácia antropológica" segundo a qual "a noção de que uma cultura, para ser uma cultura, deve ser um organismo fechado, de modo que cada uma de suas manifestação possa entender-se como uma faceta significativa da mesma entidade" (in MARSAL, 1970, p. 58) [“la noción de que una cultura, para ser una cultura, debe ser un organismo cerrado, cada una de cuyas manifestaciones pueda entenderse como una faceta significativa de la misma entidad" (in MARSAL, 1970, p. 58)]. Disso emerge, em sua leitura, a figura do intelectual quase poético da américa latina, que atua como deidade "cuando os intelectuais descobrem e adotam essas forças se transformam, natualmente, em promotores de sua iminência e de sua plenitude espiritual. Desse modo, o homem sensível, o mero pensador, é resgatado de seu isolamento e de sua impotência para transforma-se na mão que guia a história ou no servidor ou guardião de algum inexpurgável sistema de valores" (MARSAL, 1970, p. 61) ["cuando los intelectual descubren y adoptan esas fuerzas, se transforman, naturalmente, en promotores de su inminencia y de su plenitud espiritual. De este modo, el hombre sensible, el mero pensador, es rescatado de su aislamento y de su impotência para transformarse en la mano que guia la história o en el servidor o guardián de algún inexpugnable esquema de valores" (MARSAL, 1970, p. 61)].
} 
mais fácil imaginar um destino próprio, que deve constituir-se. (DEVÉS VALDÉS, 2000, p. 92, tradução nossa) $)^{33}$

Para Doris Brinkmann (2014), o interesse pelo discurso de crise que se generaliza na Espanha do começo do século tem relação com sua vitória na guerra franco-prussiana, onde Alemanha e Espanha se aproximaram em razão do inimigo em comum, a França. Na República de Weimar, inclusive, houve uma série de campanhas em favor da Espanha, que atraia pela religiosidade, pela "espiritualidade perdida" na Europa. Conservadores como Carl Schmitt louvaram essa Espanha espiritualizada, destacando a existência de uma afinidade entre as duas nações, enquanto a França seguiria sendo o território da cortesia, da superficialidade. Em 1904 é fundada na Espanha a Junta para Ampliación de Estudios y Investigaciones Cientificas que visava conferir bolsas de estudos para que espanhóis estudassem na Alemanha. Dentre os favorecidos está Ortega, que vai pra Marburgo. É o período, também, em que se abrem vários colégios alemães na Espanha, financiados pelo governo alemão e bem vistos pela elite letrada de Madri e de Barcelona. A neutralidade da Espanha na Primeira Guerra fez com que a Alemanha valorizasse ainda mais os laços com ela e possibilitou, no entreguerras, a circulação do discurso de crise que aciona, de modo direto, a figura do intelectual enquanto portador do "espírito do tempo", amplamente divulgada na Argentina. Dentre os nomes que Brinkmann destaca como "homens-ponte" entre Alemanha e Espanha encontram-se alguns dos publicadores mais frequentes na Argentina, como Unamuno, Pio Baroja, Ruben Darío, além do próprio Ortega. No mesmo sentido, Vanpaemel (2015) destaca a importância da França e da Inglaterra na divulgação do modelo alemão pelo mundo, reiterando a importância de um olhar atento às mediações da geografia intelectual no transporte dos valores que se atrelavam ao predomínio germânico.

O retorno ao autóctone fomenta também, como já delineado, as leituras anti-imperialistas. Se o positivista francês funciona como o anátema arquetípico no universo alemão, na Argentina - e em toda a América Latina, em distintos graus - essa figura passa a ser ocupada pelo norte-americano. A reaproximação com a Espanha passava, para esses nacionalistas, pela

\footnotetext{
33 "a partir del positivismo mecanicista era coerente pensar que los pueblos de nuestro continente debían seguir el mismo destino que habían señalado los más modernos. Al reivindicar en cambio lo espiritual, lo volitivo, la libertad creadora, se hace mucho más facil imaginar un destino próprio, que debe constituirse" (DEVÉS VALDEZ, 2000, p. 92).
} 
construção de uma trincheira de "comunidade espiritual", que pudesse fazer frente ao crescente imperialismo anglo-saxão. Nesse sentido, como lembra San Martín, passa a vigorar "o axioma básico de que a ciência, a cultura, a razão, não são nada se não estão ancoradas na vida, na subjetividade individual concreta, se não servem à vida pessoal e concreta dos indivíduos" (1994, p. 36, tradução nossa). ${ }^{34}$

Dessa forma, a leitura nacionalista que pretendia "revisar" a narrativa liberal sobre o país estava amparada não apenas por uma sólida rede institucional, mas também pela circulação de toda uma tradição do pensamento alemão que se opunha às "licenciosidades" da tradição liberal francesa. Alemanha e Espanha compartilhavam, nesse recorte específico, tanto do diagnóstico de crise como da solução vitalista e essencialista para seus desdobramentos. A ideia de destino histórico, com toda a dimensão trágica que tal asserção circunscreve, irmanava as demandas que se estabelecem a partir da crítica à modernidade e à desagregação dos valores que ela supostamente exigia. Meinecke, por exemplo, falando sobre a figura arquetípica de Rousseau, parece descrever o próprio gaúcho romântico dos revisionistas argentinos "o homem ideal da natureza, não corrompido e de coração virtuosamente sensível, que ele proclama, não era mais que a inversão do homem comum da ilustração" (1982, p. 136). ${ }^{35}$ Na fórmula de Vásquez-Rial, a invenção dessa tradição que transformava o gaúcho num bom selvagem passava pela "nostalgia do 'velho e manso feudalismo americano', dos criados fiéis sem outras inquietudes que seu serviço, do respeito e veneração dos subalternos, em contraposição às ideas e às cidades, o cosmopolitismo democrático" (1996, p. 97, tradução nossa). ${ }^{36}$ Braun e Cacciatore (1996) apontam, que, ao contrário das referências francesas, as espanholas contavam com um substancial lastro na comunidade de imigrantes (os ibéricos eram a segunda população, perdendo apenas para os italianos). Nesse sentido, muito embora o mito nacional tenha sido mobilizado pelas elites letradas, ele encontrava uma comunidade de sentido e uma carga semântica favorável nesses setores

\footnotetext{
34 "el axioma básico de que la ciência, la cultura, la razón no son nada si no están ancladas en la vida, en la subjetividad individual concreta, si no sirven a la vida personal y concreta de los indivíduos" (1994, p. 36).

35 "el hombre ideal de la naturaleza, no corrompido y de corazón virtuosamente sensible, que él proclama, no era más que la inversión del hombre normal de la ilustración" (1982, p. 136).

36 "Nostalgia del 'viejo y manso feudalismo americano', de los criados fieles sin más inquietud que su servicio, del respecto y veneración de los subalternos, en contraposición con las ideas y las ciudades, el 'cosmopolitismo democrático'" (1996, p. 97).
} 
que então se incorporavam à cena política e cultural. A reivindicação dos imigrantes ao discurso da tradição, nesse sentido, é menos excêntrica do que parece, na medida em que não são os filhos da aristocracia que têm de forjar um laço nacional mas, ao contrário, aqueles cujas tradições são menos evidentes e, portanto, mais carentes de legitimidade.

O que se observa é, em linhas gerais, a transformação do quadro de referências no qual se moviam os intelectuais argentinos. Se, na virada do século, a hispanofobia dos modernizadores lastreava uma atitude francamente cosmopolita e alinhada com os códigos simbólicos franceses, "mais tarde, ao contrário, se chegará a reduzir nossa autêntica cultura à ascendência espanhola, atribuindo à raiz anglo-francesa, outrora estimada como paradigmática, a própria decomposição da nacionalidade" (BIAGINI, 1989, p. 42). ${ }^{37}$ Essa mudança, portanto, da valoração das polaridades de continuidade patrimonial e simbólica, sustenta a revisão da versão liberal da história argentina e, desse modo, permite que todo o repertório nacionalista e vitalista da filosofia alemã seja posto a serviço da reaproximação com a tradição espanhola. A década de 1930 generaliza, enfim, na Argentina, o discurso de crise que se insinuava nos debates entre a cultura científica e a cultura humanista desde a virada do século. Se, teoricamente, essa mudança pode ser compreendida a partir do cotejamento das obras, esse artigo procurou mostrar que, nos âmbitos das atitudes e dos estilos de vida, os fenômenos intelectuais podem ser observados enquanto efetivas disputas culturais que envolvem não apenas o manejo e a ressignificação de tradições mas, também, o posicionamento da Argentina naquilo que Pascale Casanova chamou de a "república mundial das letras".

\footnotetext{
37 "más tarde, por lo contrario, se llegará a reducir nuestra auténtica cultura al ascendiente español, adjudicándosele a la raigambre aglofrancesa, otrora estimada como paradigmática, la mismísima descomposición de la nacionalidad" (BIAGINI, 1989, p. 42).
} 


\section{Referências bibliográficas}

ABELLAN, José Luis. Filosofia española en America (1933-1966). Madri: Seminarios Editoriales, 1967.

ALTAMIRANO, Carlos. Um mundo em crise. Tempo Social, São Paulo, v. 21, n. 2, p. 1134, 2009. Disponível em:<https://www.revistas.usp.br/ts/article/view/12591>. Acesso em: 18 jul. 2019. doi: https://doi.org/10.1590/S0103-20702009000200002.

ALTAMIRANO, Carlos (org.). Historia de los intelectuales en América Latina: II. Las aventuras de la ciudad letrada. Buenos Aires: Katz, 2010.

ALTAMIRANO, Carlos \& SARLO, Beatriz. Ensayos Argentinos: de Sarmiento a la vanguardia. Buenos Aires: Ariel, 1997.

ANGENOT, Marc. Malaise dans l'idée de progrès (1889). Mots, Lyon, n. ${ }^{19}$, p. 5-22, 1989.

BABINI, José. Historia de la ciencia en la Argentina. Buenos Aires: Ediciones Solar, 1986.

BEIRED, José Luis Bendicho. O hispano-americanismo historiográfico: Espanha e América na perspectiva de Ricardo Leve e Rafael Altamira. História Unisinos, São Leopoldo, v. 13, n. 1, p. 43-53, 2009. Disponível em: <http://revistas.unisinos. br/index.php/historia/article/view/5072>. Acesso em: 19 jul. 2019. doi: https:// doi.org/10.4013/htu.2009.131.04.

BEN-DAVID, Joseph. O papel do cientista na sociedade: um estudo comparado. Tradução: Dante Moreira Leite. São Paulo: Edusp, 1974.

BEN-DAVID, Joseph. Social factors in the origins of a new science: the case of psychology. American Sociological Review, Washington, D.C., v. 3, n. 4, p. 451-465, 1996.

BENDER, Thomas. Intellect and public life: essays on the social history of academic intellectuals in the Unites States. Baltimore: John Hopkins University Press, 1997.

BIAGINI, H. Filosofia Americana e identidad: el conflictivo caso argentino. 1. Ed. Buenos Aires: EUDEBA, 1989.

BLANCO, Alejandro. Razón y modernidad: Gino Germani y la sociología en la Argentina. Buenos Aires: Siglo Veintiuno, 2006.

BOS, Jaap. Les types de marginalisation dans leur relation constitutive au discours. L'Homme et la Société, Paris, v. 1, n. 167/168/169, p. 177-201, 2008. Disponível em: $<$ https://www.cairn.info/revue-l-homme-et-la-societe-2008-1-page-177.htm>. Acesso em: 18 Jul. 2019. doi: https://doi.org/10.3917/lhs.167.0177.

BOURDIEU, Pierre. Systèmes d'enseignement et systèmes de pensée. L'Homme et la Société, Paris, n. 6, p. 209-210, 1967. Disponível em: <https://www.persee.fr/doc/homso_0018-4306_1967_num_6_1_1093_t1_0209_0000_4>. Acesso em: 19 jul. 2019.

BOURDIEU, Pierre. Meditações pascalianas. Tradução: Sergio Miceli. Rio de Janeiro: Bertrand Brasil, 2001.

BOURDIEU, Pierre. As condições sociais da circulação internacional das ideias. Tradução: Fernanda Abreu. Enfoques, Rio de Janeiro, v. 1, n. 1, p. 6-15, 2002. Disponível em: <https://revistas.ufrj.br/index.php/enfoques>. Acesso em: 19 jul. 2019.

BOURDIEU, Pierre. A distinção: uma crítica social da faculdade do juízo. Tradução: Pedro Duarte. Lisboa: Edições 70, 2010. 
BOURDIEU, Pierre $\mathcal{E}$ PASSERON, Jean-Claude. Los herederos: los estudiantes y la cultura. $3^{\text {a }}$ edição. Buenos Aires: Siglo Veintiuno, 2013.

BRAUN, Clara $\mathcal{E}$ CACCIATORE, Julio. El imaginario interior: el intendente Alvear y sus herederos: metamorfosis e modernidad urbana. In: VÁSQUEZ-RIAL, Horacio (org.). Buenos Aires (1880 - 1930): la capital de un imperio imaginario. Madri: Alianza Editorial, 1996, p. 31-71.

BRILLANT, Bernard. Les clercs de 68. Paris: PUF, 2003.

BRINKMANN, Doris. La teoría de la transferencia cultural y la construcción de un referente cultural alemán em la España de entreguerras (1919-1936). Tese de doutorado em Filologia, Universidad Complutense de Madrid, Madri, 2014.

BRUNO, Paula. La vida letrada porteña entre el 1860 y el fin de siglo: coordenadas para un mapa de la elite intelectual. Anuario IEHS, Tandil, v. 24, p. 339-368, 2009.

BUCHBINDER, Pablo. Historia de la Facultad de Filosofía y Letras: Universidad de Buenos Aires. Buenos Aires: Eudeba, 1997.

BUCHBINDER, Pablo. Los Quesada: letras, ciencia y política en la Argentina, 1850-1934. Buenos Aires: Edhasa, 2012.

BURROW, John W. La crisis de la razón: el pensamiento europeo. 1848-1914. Tradução: Jordi Beltrán. Barcelona: Editorial Crítica, 2000.

CANÉ, Miguel. Ensayos. Buenos Aires: Imprenta de la Tribuna, 1877.

CANÉ, Miguel. En viaje (1881-1882). Buenos Aires: Talleres Gráficos Argentinos de L. Rosso, 1928.

CASANOVA, Pascale. A republica mundial das letras. Tradução: Marcia Appenzeller. São Paulo: Estação Liberdade, 2002a.

CASANOVA, Pascale. Consécration et acumulation de capital littéraire: la traduction comme échange inégal. Actes de la Recherche em Sciences Sociales, Paris, v. 144, p. 7-20, 2002b.

CHARLE, Christophe. La republique des universitaires: 1870-1940. Paris: Éditions du Seuil, 1994.

CHARLE, Christophe. Les intellectuels en Europe au XIXe siècle: essai d'histoire comparée. Paris: Éditions du Seuil, 1996.

COHN, Gabriel. Crítica e Resignação. Max Weber e a Teoria Social. São Paulo: Ed. Martins Fontes, 2003.

COLLINS, Randall. The sociology of philosophies: a global theory of intellectual change. Cambridge: Harvard University Press, 2001.

COSER, Lewis Alfred. Hombres de ideas: el punto de vista de un sociólogo. Tradução: Ivonne de la Peña. Ciudad de México: Fondo de Cultura Económica, 1968.

DARÍO, Rubén. El triunfo de Calibán. El Tiempo, Buenos Aires, 20/05/1898.

DE TORRE, Guillermo. Madrid: meridiano intelectual de hispanoamerica. La Gaceta Literaria, Madri, n. 8, p. 1, 1927.

DEVÉS VALDÉS, Eduardo. El pensamiento latinoamericano en el siglo XX: entre la modernización y la identidad. Tomo I: Del Ariel de Rodó a la CEPAL (1900-1950). Buenos Aires: Bilbos, 2000. 
ESPAGNE, Michel. En deçà du Rhin: l'Allemagne des philosophes français au XIXe siècle. Paris: Cerf, 2004.

FUNES, Patricia. Salvar la nación: intelectuales, cultura y política en los años veinte latinoamericanos. Buenos Aires: Prometeo Libros, 2006.

FUSI AIZPURÚA, Juan Pablo. La crisis de la conciencia europea. In: CABRERA CALVO-SOTELO, Mercedes et al. (comp.). Europa en crisis: 1919-1939. Madri: Editorial Pablo Iglesias, 1991, p. 327-342.

QUESADA, V. em VALVEZ, Victor. Memorias de un viejo: escenas de costumbres de la República Argentina. Buenos Aires: Ediciones Solar, 1942.

GIL VILLEGAS, Francisco. Los profetas y el mesías: Lukács y Ortega como precursores de Heidegger en el Zeitgeist de la Modernidad (1900-1929). Ciudad de México: Fondo de Cultura Económica, 1998.

GIRBAL-BLACHA, Noemí María et al. (org.). Estado, sociedad y economía en la Argentina (1930-1997). Buenos Aires: Universidad Nacional de Quilmes, 2001.

GORELIK, Adrián. A Buenos Aires de Ezequiel Martines Estrada. Tempo Social, São Paulo, v. 21, n. 2, p. 35-59, 2009. Disponível em: <http://www.scielo.br/scielo. php?script=sci_arttextEpid=S0103-20702009000200003 >. Acesso em: 19 jul. 2019. doi: http://dx.doi.org/10.1590/S0103-20702009000200003.

GRAMUGLIO, Maria Teresa. Sur: uma minoria cosmopolita na periferia ocidental. Tempo Social, São Paulo, v. 19, n. 1, p. 51-69, 2007.

GROUSSAC, Paul. Del Plata al Niágara. Buenos Aires: Ed. Jesús Menendez, 1925.

GUTIÉRREZ, Juan María et al. El salón literario: estudio preliminar de Weinberg. Buenos Aires: Hachette, 1958.

HARTOG, François. Regimes de historicidade: presentismo e experiências do tempo. Belo Horizonte: Autêntica, 2014.

HARVEY, David. Paris: capital da modernidade. Tradução: Magda Lopes. São Paulo: Boitempo, 2015.

HEILBRON, J. The rise of social theory. Contradictions of modernity. Great Britain. University of Minessota Press, 1995.

HEILBRON, Johan $\mathcal{E}$ SAPIRO, Gisèle. La traduction littéraire, un objet sociologique. Actes de la recherche en sciences sociales, Paris, n. 144, p. 3-5, 2002. Disponível em: $<$ www.persee.fr/doc/arss_0335-5322_2002_num_144_1_2803>. Acesso em: 18 jul. 2019. doi: https://doi.org/10.3406/arss.2002.2803.

JACOB, Christian (dir.). Lieux de savoir: espaces et communautés. Paris: Albin Michel, 2007.

KING, John. Sur: a study of the Argentine Literary Journal and its role in development of a culture, 1931-1970. Cambridge: Cambridge University Press, 1986.

KOSELLECK, R. Crítica e Crise. Uma contribuição à patogênese do mundo burguês. Trad. Luciana Villas Boas Castelo Branco. UERJ, Rio de Janeiro: Ed. Contraponto, 1999.

KOSELLECK, Reinhart. The practice of conceptual history: timing history, spacing concepts. Redwood City: Stanford University Press, 2002.

KOSELLECK, Reinhart. Futuro passado: contribuição à semântica dos tempos históricos. Rio de janeiro: Contraponto, 2006. 
LEPENIES, Wolf. Las tres culturas: la sociología entre la literatura y la ciencia. Ciudad de México: Fondo de Cultura Económica, 1985.

LÓPEZ SANCHEZ, José María. Intelectualidad española en América Latina: la junta para ampliación de estudios y sus redes culturales. Sociotam, Ciudad Victoria, v. 17, n. 1, p. 115-140, 2007.

MALLEA, Eduardo. Historia de una pasión Argentina. Buenos Aires: Editorial Sudamericana, 1961.

MARTÍNEZ ESTRADA, Ezequiel. Radiografía de la Pampa. Madri: CSIC, 1991.

MARTÍNEZ ESTRADA, Ezequiel. La cabeza de Goliath. Buenos Aires: Editorial del Cardo, 2003. Disponível em:<http://www.biblioteca.org.ar/libros/656459.pdf>. Acesso em: 2 jul. 2015.

MEINECKE, F. El historicismo y sus genesis. Mexico: Fondo de Cultura Económica, 1982.

MERLIO, Gilbert. Le pessimisme culturel entre la France et l'Allemagne. Mil neuf cent, Paris, n. 14, p. 41-67, 1996.

MICELI, Sergio. Vanguardas em retrocesso. São Paulo: Companhia das Letras, 2014.

MICELI, Sergio. Sonhos da periferia. São Paulo: Companhia das Letras, 2018.

MILO, D. La bourse mondiale de la traduction : un baromètre culturel ?. In: Annales. Économies, Sociétés, Civilisations. 39 année, N. 1, 1984. pp. 92-115.

OCAMPO, V. Testimonios. Autobiografia II. O Império Insular. Buenos Aires: Ediciones Revista Sur, 1980.

ORTEGA Y GASSET, José. El tema de nuestro tiempo. Madri: Revista de Occidente, 1956.

ORTEGA Y GASSET, José. A rebelião das massas. Rio de Janeiro: Ed. Livros Ibero-americanos, 1971.

ORTEGA Y GASSET, José. Obras completas, v. 4. Madri: Alianza Editorial: Revista de Occidente, 1983.

PASTERNAC, Nora. La Revista Sur: un cierto americanismo. In: CRESPO, Regina. (coord.). Revistas en América Latina: proyectos literarios, políticos y culturales. Ciudad de México: CIALC: Eón, 2010, p. 121-133.

PELLETIER, Nicole. Crises et conscience de crise dans les pays de langue allemande (années 20 et 30). Bordeaux: Presses Universitaire Bordeaux, 2008.

PINTO, Louis. L'inconscient scolaire des philosophes. Actes de la Recherche en Sciences Sociales, Paris, n. 135, p. 48-57, 2000. Disponível em:<https://www.persee.fr/doc/ arss_0335-5322_2000_num_135_1_2700>. Acesso em 18 jul. 2019. doi: https:// doi.org/10.3406/arss.2000.2700.

PINTO, Louis. Le commerce des idées philosophiques. Paris: Éditions du Croquant, 2009.

RAPOPORT, Mario E SEOANE, María. Buenos Aires: historia de una ciudad, t. 1. Buenos Aires: Planeta, 2007.

RINGER, Fritz. Fields of knowledge: french academic culture in comparative perspective. 18901920. Cambridge: Cambridge University Press, 1992.

RINGER, Fritz. O declínio dos mandarins alemães. São Paulo: Edusp, 1999.

RODÓ, José Enrique. Ariel. Madri: Espasa-Calpe, 1975 
ROLLAND, Denis. A crise de um certo universalismo: o modelo cultural e político. In: PERRONE-MOISÉS, Leyla (org.). Do positivismo à desconstrução: ideias francesas na América. São Paulo: Edusp, 2004, p. 237-296.

ROMERO, José Luis. Latinoamerica: las ciudades y las ideas. Buenos Aires: Siglo Veintiuno, 1976.

RUVITUSO, Clara. Diálogos existenciales: la filosofía alemana en la Argentina peronista (1946-1955). Madri: Iberoamericano: Vervuet, 2015.

SAN MARTÍN, Javier. Ensayos sobre Ortega. Madri: Uned, 1994.

SAPIRO, Gisèle. Translation and the field of publishing. Translation Studies, Abington-on-Thames, v. 1, n. 2, p. 154-166, 2008. Disponível em: <https://www. tandfonline.com/doi/abs/10.1080/14781700802113473>. Acesso em 19 jul. 2019. doi: https://doi.org/10.1080/14781700802113473.

SAPIRO, Gisèle. Modelos de intervención política de los intelectuales: el caso francés. Prismas, Bernal, v. 15, n. 2, p. 129-154, 2011. Disponível em: <http://www. redalyc.org/pdf/3870/387036813001.pdf>. Acesso em: 18 jul. 2019.

SAPIRO, Gisèle. La circulation des sciences humaines et sociales en traduction: enjeux et obstacles à l'heure de la globalisation. Traduire, Marseille, n. 227, p. 5-15, 2012. Disponível em: $<$ http://journals.openedition.org/traduire/465>. Acesso em: 19 jul. 2019. doi: https://doi.org/10.4000/traduire.465.

SARLO, Beatriz. La imaginación técnica: sueños modernos de la cultura argentina. Buenos Aires: Nueva Visión, 1997.

SARLO, Beatriz. A paixão e a exceção: Borges, Eva Perón, Montoneros. São Paulo: Companhia das Letras; Belo Horizonte: Editora UFMG, 2005.

SARLO, Beatriz. La batalla de las ideas (1943-1973). Buenos Aires: Emecé, 2007.

SARLO, Beatriz. Modernidade periférica: Buenos Aires 1920 e 1930. Tradução: Júlio Pimentel. São Paulo: Cosac Naify, 2010.

SARLO, Beatriz. El imperio de los sentimientos: narraciones de circulación periódica en la Argentina (1917-1927). Buenos Aires: Siglo Veintiuno, 2011.

SARLO, Beatriz. Intelectuais. In: Caggiano, Sergio \& Grimson, Alejandro (coord.). Antología del pensamiento crítico argentino. Buenos Aires: Siglo Ventiuno, 2015, p. 195-253.

SCHORSKE, Carl. Fin-de-siècle Vienna: politics and culture. New York: Vintage Books, 1981.

SEBRELI, Juan José. La saga de los Anchorena. Buenos Aires: Editorial Sudamericana, 1985.

SILVA, Paulo Renato da. As revistas Sur, Contorno e a nova geração intelectual argentina. Revista Eletrônica da ANPHLAC, São Paulo, n. 4, p. 64-84, 2005.

SIMMEL, Georg. Filosofía del dinero. Madri: Alianza, 1977.

SIMMEL, Georg. As grandes cidades e a vida do espírito (1903). Revista Maná, Rio de Janeiro, v. 11, n. 2, p. 577-591, 2005. Disponível em: <http://www.scielo.br/ scielo.php?script=sci_arttextEpid=S0104-93132005000200010>. Acesso em: 19 Jul. 2019. doi: http://dx.doi.org/10.1590/S0104-93132005000200010.

SVAMPA, Maristella. El dilema argentino: civilización o barbarie: de Sarmiento al revisionismo peronista. Buenos Aires: El Cielo por Asalto, 1994.

TABORDA, Saul. La crisis espiritual y el ideario argentino. Santa Fé: Universidad nacional del Litoral, 1941. 
TEDESCO, Alexandra Dias Ferraz. Dios nos salve de las ciencias sociales: os relatórios de Ernesto Quesada e o debate sobre as humanidades nas universidades argentinas. Tempo Social, São Paulo, v. 30, n. 2, p. 277-300, 2018. Disponível em: <http://www.scielo.br/scielo.php?script=sci_abstractE ${ }^{2}$ i$\mathrm{d}=$ S0103-20702018000200277 $\mathcal{E}$ lng=en $\mathcal{E} \mathrm{nrm}=\mathrm{i}$ so $\mathcal{E}$ tlng=pt $>$. Acesso em: 19 jul. 2019. doi: http://dx.doi.org/10.11606/0103-2070.ts.2018.124682.

TERÁN, Oscar (coord.). Ideas en el siglo: intelectuales y cultura en el siglo XX latinoamericano. Buenos Aires: Siglo Veintiuno, 2004.

TERÁN, Oscar. Vida intelectual em el Buenos Aires fin-de-siglo (1880-1910): derivas de la "cultura científica". Buenos Aires: Fondo de Cultura Económica, 2008.

TONNIES, Ferdinand. Comunidade e sociedade como entidades típico-ideais. In: FERNANDES, Florestan (org.). Comunidade e Sociedade. São Paulo: Edusp, 1995, p. 96-116.

VANPAEMEL, G. The german model of laboratory Science and the european pheriphery (1860 - 1914) in SIMÕES, A; DIOGO, M. P.; GAVROGLU, K. (org) Sciences in the universities of Europe. Nineteenth and Twentieth Centuries. Academic Landscapes. Springer, 2005.

VÁSQUEZ-RIAL, Horacio (org.). Buenos Aires (1880 - 1930): la capital de un imperio imaginario. Madri: Alianza Editorial, 1996.

VÁZQUEZ, Karina. De la modernidad y sus mapas: Revista de Occidente y la nueva generación en la argentina de los años veinte. Estudios Interdisciplinarios de América Latina y el Caribe, Tel Aviv, v. 14, n. 1, p. s/p. 2003. Disponível em: <http://eial.tau.ac.il/index.php/eial/article/view/934>. Acesso em: 19 jul. 2019.

VIALA, Alain. Naissance de l'écrivain. Paris: Les Éditions de Minuit, 1985.

VIÑAS, David. Literatura argentina y política: de los jacobinos porteños a la bohemia anarquista. Buenos Aires: Santiago Arcos, 2005.

WEBER, Max. Economía y sociedad: tipos de comunidad religiosa. Tradução: Eugenio Ímaz Echeverría. Ciudad de México: Fondo de Cultura Económica, 1944.

WEBER, Max. Tipos de comunidad religiosa (sociología de la religión). In: WEBER, Max. Economía y Sociedad, t. 1. Havana: Instituto Cubano del Libro, 1964.

WEBER, Max. Ensaios de sociologia. 2a edição. Rio de Janeiro: Zahar, 1971.

WEBER, Max. Metodologia das ciências sociais. Campinas: Editora Unicamp, 2017.

WILLIAMS, Raymond. Campo e cidade na história e na literatura. São Paulo: Companhia das Letras, 1990.

Recebido: 07/02/2019 - Aprovado: 17/06/2019

Editores responsáveis pela publicação:

Júlio Pimentel Pinto e Flavio de Campos 